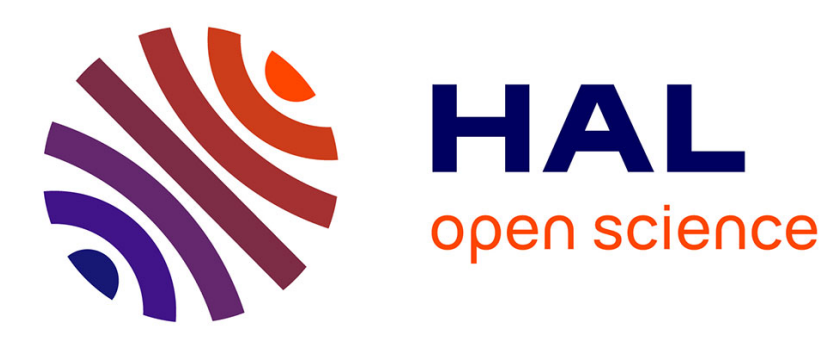

\title{
Drivers of entrepreneurship and post-entry performance of newborn firms in developing countries
}

Francesco Quatraro, Marco Vivarelli

\section{To cite this version:}

Francesco Quatraro, Marco Vivarelli. Drivers of entrepreneurship and post-entry performance of newborn firms in developing countries. World Bank Research Observer, 2015, 30 (2), pp.277-305. 10.1093/wbro/lku012 . hal-01071511

\section{HAL Id: hal-01071511 https://hal.science/hal-01071511}

Submitted on 17 Nov 2014

HAL is a multi-disciplinary open access archive for the deposit and dissemination of scientific research documents, whether they are published or not. The documents may come from teaching and research institutions in France or abroad, or from public or private research centers.
L'archive ouverte pluridisciplinaire HAL, est destinée au dépôt et à la diffusion de documents scientifiques de niveau recherche, publiés ou non, émanant des établissements d'enseignement et de recherche français ou étrangers, des laboratoires publics ou privés. 


\title{
DRIVERS OF ENTREPRENEURSHIP AND POST- ENTRY PERFORMANCE OF NEWBORN FIRMS IN DEVELOPING COUNTRIES
}

\author{
Francesco Quatraro ${ }^{\mathrm{a}, \mathrm{b}}$ \\ Marco Vivarelli ${ }^{\mathrm{c}, \mathrm{d}, \mathrm{e}^{*}}$
}

a) GREDEG, CNRS et Université de Nice Sophia Antipolis, Nice

b) BRICK, Collegio Carlo Alberto, Torino

c) Università Cattolica del Sacro Cuore, Milano and Piacenza

d) SPRU, University of Sussex

e) Institute for the Study of Labour (IZA), Bonn

\begin{abstract}
The aim of this paper is to provide an updated survey of the "state of the art" in entrepreneurial studies, with a particular focus on developing countries (DCs). In particular, the same concept of "entrepreneurship" will be critically discussed, then moving to the institutional, macroeconomic and microeconomic conditions affecting the entry of new firms and the post-entry performance of newborn firms.
\end{abstract}

Keywords: Entrepreneurship; new firm; innovation, development.

JEL Classification:L26, O12.

*Corresponding Author:

Prof. Marco Vivarelli

Facoltà di Economia

Università Cattolica

Via Emilia Parmense 84

29122 Piacenza

marco.vivarelli@unicatt.it 


\section{Introduction}

According to Schumpeter (1934), entrepreneurship is a driving force of innovation, and more generally an engine for economic development (see Audretsch, Keilbach and Lehmann, 2006; Koellinger and Thurik, 2012; and, for a comprehensive survey, Van Praag and Versloot, 2007).

As detailed by Wennekers and Thurik (1999) and Dejardin (2011), new firm formation may play a crucial role in fostering competition, inducing innovation and fostering the emergence of new sectors. Ultimately, new firms may substantially contribute to job creation, provided that the net effect of new entrants brings about overall market growth (see Malchow-Møller, Schjerning and Sørensen, 2011).

The relationship between the rate of new firm creation and economic development is however heterogeneous across countries. The distinction between advanced and developing countries (DCs) is especially important in this respect. Wennekers et al. (2005) indeed showed that the link between entrepreneurial dynamics and economic performances is not monotonic. On the contrary, they found evidence of a U-shaped relationship between the level of development and the rate of entrepreneurship (see also Ligthelm, 2011, p.163). This suggests that entrepreneurship does not yield the same effects no matter where it takes place. Based on this contribution, Amoròs and Cristi (2008) analyzed the Latin America evidence by adopting an interpretative framework based on the Porter's (1990) scheme of country economic development, which identifies three stages: factor-driven, efficiencydriven and innovative-driven. They provided further support to the U-shaped hypothesis, and in particular they show that Latin America's countries are clustered in the downward part of the curve.

Such heterogeneous evidence at the aggregate level can be better understood when shifting the focus to the micro foundations of entrepreneurship. Since the seminal contribution by Baumol (1990) we have known that 'Shumpeterian' innovative entrepreneurs' coexist with 'defensive and necessity entrepreneurs', the latter being those who enter a new business not because of market opportunities and innovative ideas, but 
merely because they need an income to survive ${ }^{1}$. For obvious reasons, this kind of 'survival-driven' self-employment is particularly diffused in DCs (Naudé, 2009 and 2010; Desai, 2009), where poverty and lack of formal opportunities in the wage sector often push a large number of people into 'entrepreneurial' activities ranging from street vending to traditional and personal services (in most cases within the informal sector of the economy, see Ihrig and Moe, 2004; Maloney, 2004; Sonobe, Akoten and Otsuka, 2011). The prevalence of 'survival driven' entrepreneurs in DCs is often associated to the choice to stay small and informal, rather than participating to the formal sector of the economy (see Section 3; Klapper, Amit and Guillén, 2010; Desai, 2009). This is one of the reasons why the effects of entrepreneurship on economic performances of DCs appear to be problematic. However, Amoròs and Cristi (2011) study the relationship between entrepreneurship and human development indicators and provide empirical evidence to the hypothesis that, while this kind of entrepreneurship is hardly able to trigger the economic performance of DCs, it contributes nonetheless to the reduction of inequalities by affecting the wealth distribution in the society. On similar grounds, Naudè, Amoros and Cristi (2011) posit that the effects of entrepreneurship in DCs should be analyzed by looking at broader and more non-material and subjective measures of human well-being. Their findings suggest that entrepreneurship in DCs may matter for individual and societal development, beyond the mere increase of GDP.

The emphasis on the development stage of countries calls for a special attention also to the evolution of their industrial structure. Since the seminal contributions by Marshall (1919) and Kuznets (1930), and we have known indeed that a country's economic performance is much related to the main sectors in which it shows a comparative advantage. The fortunes of countries as well as the dynamics of entry, exit and growth are therefore closely related to the relative stage of the lifecycle of their industries (Klepper, 1997).

\footnotetext{
${ }^{1}$ The identification of necessity entrepreneurs is a non-trivial task. In the recent literature the distinction between necessity and opportunity driven entrepreneurs is grasped by using the Global Entrepreneurship Monitor (GEM) data. The GEM measures 'necessity-driven' entrepreneurship by including the question 'Are you involved in this start-up [this firm] to take advantage of a business opportunity or because you have no better choices of work?' (Naudé, Amoros and Cristi, 2011). In more general terms, empirical studies single out "necessity entrepreneurs" either as those who come from an unemployment status or as those answering to ad-hoc questionnaires, revealing to be pushed into "entrepreneurship" by a concern about future career developments or by the fear of becoming unemployed (see also Section 4.6).
} 
In this respect, the empirical evidence concerning industrial dynamics also casts much doubt on the progressive potentialities of business start-ups. Firstly, survival rates for new firms are strikingly low: the available econometric evidence shows that more than $50 \%$ of new firms exit the market within the first five years of activity (see Dunne, Roberts and Samuelson, 1989; Reid 1991; Geroski, 1995; Mata, Portugal and Guimaraes, 1995; Audretsch and Mahmood, 1995; Audretsch, Santarelli and Vivarelli, 1999a; Johnson, 2005).

Secondly, entry and exit rates are significantly correlated (what is called "turbulence", see Beesley and Hamilton, 1984); this is one of the uncontroversial 'stylized facts' of the entry process according to Geroski (1995, p. 424), who pointed out that the "mechanism of displacement, which seems to be the most palpable consequence of entry, affects young, new firms more severely" (see also Baldwin and Gorecki, 1987 and 1991). Indeed, entry and exit rates have been found to be positively correlated across industries in both OECD countries (see Bartelsman, Scarpetta and Schivardi, 2005) and in DCs (see Bartelsman, Haltinwanger and Scarpetta, 2004²).

This evidence opens the way to some considerations regarding the alleged role of entry as a vehicle for technological upgrading, productivity growth and employment generation. Consistently, one should be very cautious in seeing entrepreneurship measured as new firm formation as the main driver of development for a DC. If entry were indeed driven mainly by technological opportunities, growing sales and profit expectations, one would observe a negative cross-sectional correlation between entry and exit rates, in particular over short time intervals.

By the same token, new firm formation may be more or less conducive to technological upgrading and industry growth, according to the different sectors in which it occurs. For instance, 'new technology-based firms' (NTBFs; see Acs and Audretsch, 1990; Colombo, Delmastro and Grilli, 2004) in advanced manufacturing and ICT services certainly play a different role compared with small-sized start-ups in traditional sectors.

These considerations concerning the role of the industrial structure are particularly relevant for the DCs, where the dominant role of traditional and low-tech sectors renders

\footnotetext{
${ }^{2}$ The authors used a sample of 22 countries (14 European, 6 Latin American, the US and Canada) and found that the correlation between entry and exit rates across industries in 1990 was positive and significant in the vast majority of cases (Bartelsman, Haltinwanger and Scarpetta, 2004, p.21, Table 6).
} 
turbulence more likely and the presence of progressive/innovative entrepreneurs an exception.

Within this context, the rest of the paper is organized as follows: Section 2 is devoted to the institutional context (which is often the main deterrent to entrepreneurship in the DCs); Section 3 moves to the microeconomic and personal drivers of entrepreneurship; Section 4 discusses the link between ex-ante characteristics and postentry performance of newborn firms, while Section 5 briefly concludes.

\section{Contextual factors and institutional constraints}

Together with industrial characteristics (see Section 1), the growth of a newborn firm is affected by a larger set of variables which have to do with the general macroeconomic business climate and with a wide range of institutional factors (see Acs and Audretsch, 1990; Geroski and Schwalbach J., 1991; Audretsch, 1995).On the whole, previous research has proved that market failures, the infrastructure endowment and the regulatory and legal conditions are important determinants of the post-entry performance of newborn firms. While this is true even for the developed countries, "a fortiori" these institutional constraints may play a crucial role in the developing countries, with a larger impact moving down from the middle-income to the low-income DCs.

At a general level, the growth of small entrepreneurial firms is obviously constrained by the overall state of the economy and the economic cycle is indeed much important for what concerns the availability of exploitable business opportunities (see Nichter and Goldmark, 2009). However, the different entrepreneurial dynamics introduced in the previous section engender a composite response to business cycles. Indeed, in recession phases the reduction of opportunity-driven Schumpeterian entrepreneurs may well be accompanied by the expansion of the necessity-driven ones (Pisani and Pagan, 2004).

DCs are also characterized by several market failures which severely hamper the post-entry growth potentialities of entrepreneurial activities. As extensively discussed in Tybout (2000), Aterido, Hallward-Driemeier and Pagés, (2009) and Vivarelli (2012) 
imperfections in the credit and financial markets, a non-transparent regulatory environment, the lack of infrastructures and the high incidence of bribing are important hindering factors affecting firm's growth in DCs.

Starting with capital markets, Rajan and Zingales (1998) and Beck et al. (2008) clearly show that firms in financially dependent industries grow much faster in financially developed countries; in contrast, new small firms in DCs are credit and equity rationed in the vast majority of cases because their financial markets are underdeveloped (see Ayyagari, Demirgüç-Kunt, and Maksimovic, 2008; Lian, Sepehri and Foley, 2011 and Section 4.2.2 below). In fact, capital markets in DCs are characterized by: 1) a lower depth (measured, for instance, by a low ratio of bank deposits to GDP; see Paravisini, 2008, for the case of Argentina; Banerjee and Duflo, 2004, for the case of India); 2) by a lower level of competition between financial intermediaries generating misallocation of funds (see Banerjee, Duflo and Munshi, 2003, studying misallocation of capital in India; Cole, 2009, discussing agricultural credit in India); 3) by higher information asymmetries due to institutional and infrastructural underdevelopment (see Klapper and Love, 2011, for a general discussion, while Canales and Nanda (2008) discuss lending to small businesses in Mexico).

By the same token, a non-transparent regulatory environment with regard to labor market rules, taxation, red tape procedures, property rights and bankruptcy laws, is particularly harmful to firms' growth in DCs and may be fatal for young entrepreneurial activities (see Goedhuys and Sleuwaegen 1999; Sleuwaegen and Goedhuys, 2002; Beck, Demirgüç-Kunt and Maksimovic, 2005; Lee et al., 2011). For instance, in a recent study, Ardagna and Lusardi (2010), dealing with GEM microdata from 37 countries including 8 DCs, showed that stringent entry regulation, soft contract enforcement rules and labor market rigidities play an important role in hindering entrepreneurship and in strengthening the adverse impact of risk aversion. Moreover, inefficient regulation may hinder the growth of small firms in DCs as they may fear the effects of red tape and higher taxes (De Soto, 1989). By the same token, the regulatory framework often involves counterproductive policy measures originally thought for supporting small firms, but actually prevent firm's growth. Indeed, the presence of subsidies addressed to SMEs may push entrepreneurs to keep the size of the firm unchanged - or at least below a given 
threshold - in order to keep being eligible for government funding (Little, Mazumdar and Page, 1987; Mitra and Pingali, 1999).

Moreover, in a developing country context, a prominent role is played by the wide diffusion of bribing, which may abort any chance of growth of a fragile new entrepreneurial activity ${ }^{3}$. For instance, Fisman and Svensson (2007), using data collected from 126 Ugandan firms, show that a $1 \%$ increase in the bribery rate implies a reduction of $3 \%$ in firm sales growth. Obviously, corruption may amplify the hampering role of credit constraints (see above) when it involves bank officials responsible for screening the entrepreneurial initiatives (see Beck, Demirgüç-Kunt and Maksimovic, 2005) ${ }^{4}$.

Finally, the lack of an adequate infrastructural endowment including roads and railways, basic utilities such as electricity and water supply, and ICT networks, is singled out by the literature as a significant shortcoming in preventing young and small firms in DCs from growing (see Aterido, Hallward-Driemeier and Pagés, 2009; Goedhuys and Sleuwaegen, 20105\% Ghani, Kerr, and O'Connell, 2011).

Having discussed the role of the macroeconomic and institutional conditions, we now move the focus of this study on the microeconomic and personal characteristics that may play a role in determining the entry and post-entry performance of new firms in the DCs.

\section{The microeconomic determinants of entry}

In the traditional microeconomic textbook narrative, the creation of new firm is driven by profit expectations, economic growth and technological opportunities

\footnotetext{
${ }^{3}$ Aterido, Hallward-Driemeier and Pagés (2009, p.10), using evidence from the World Bank Enterprise Surveys, show that $42 \%$ of firms declare they have paid bribes, with an average amount paid of $1.5 \%$ of sales.

${ }^{4}$ Aterido, Hallward-Driemeier and Pagés (2009) provides a slightly different picture, showing that the effect of corruption on growth is different across different size classes. In particular, corruption seems to have no effect on medium-sized firms and some negative effects on small firms, while it would help micro firms to grow. This can be explained by the fact that often very small firms in DCs do not comply with all the prescriptions of business regulation, and moreover they also stay persistently in the informal sector. Paying bribes may therefore turn out to be less costly than compliance (see also Vial and Hanoteau, 2010).

${ }^{5}$ The authors, using data from the World Bank Investment Climate Survey covering 947 manufacturing SMEs in 11 Sub-Saharan countries, show that firms with their own transport facilities and their own website exhibit higher growth rates, measured in terms of employment creation.
} 
(Mansfield, 1962; Acs and Audretsch, 1989a and 1989b; Geroski, 1995), while deterred by both exogenous and endogenous entry barriers (Geroski and Schwalbach, 1991; Sutton, 1991; Arauzo-Carod and Segarra-Blasco, 2005).

However, the main limitation of the textbook approach is that it focuses on market mechanisms ("pull factors")and may obscure the decision-making process at the level of the individual $^{6}$ (see Winter, 1991), thus underestimating the factors behind the entrepreneur's motivation in starting a new business. Indeed, some $20^{\text {th }}$ century authors such as Knight (1921), Schumpeter (1934 and 1939) and Oxenfeldt (1943) drew attention to the characteristics of the founder of a new firm. Following their contributions, we are aware that important individual determinants may act as "push factors" and be related both to environmental circumstances and to the potential founder's personal characteristics.

For instance, the specific local/sectoral labor market plays an important role given that the vast majority of new founders, approx. $2 / 3$ of them, were previously employed/located in the same geographical area and the same sector, the rest being young people starting their first job experience, or ex-entrepreneurs, or founders moving in from an outside region (see Vivarelli, 1991; Storey, 1994; Cressy, 1996; Arrighetti and Vivarelli, 1999; Shane, 2000; Stam, 2007). Therefore, entrepreneurship is strongly characterized by sectoral and locational inertia, thus turning out as a phenomenon affected by a significant persistence (see Fritsch and Mueller, 2007).

Within this framework, new firm formation can be modeled as an income choice based on a comparison between the wage earned in the previous job and the expected profit as an entrepreneur starting a new business in the same sector and in the same geographical area (see Creedy and Johnson, 1983; Vivarelli, 1991; Foti and Vivarelli, 1994; Audretsch, 1995; Geroski, 1995; Vivarelli, 2004; for the DCs, see Lévesque and Shepherd, 2004). This means that entry may have a counter-cyclical component and may well be induced by industrial restructuring and decreasing real wages rather than by buoyant demand expectations and an appropriate endowment of entrepreneurial capabilities (see Highfield and Smiley, 1987; Hamilton, 1989).

\footnotetext{
${ }^{6}$ In the conventional approach, entrepreneurship is generally measured as the number of new firms relative to the size of the existing population of businesses in a given industry. In contrast, if the individual 'push factors' are taken into account fully, new firms have to be related to the labour force (for further discussion, see Santarelli, Carree and Verheul, 2009; Vivarelli, 2007).
} 
Pushing this argument further, founding a new firm may be an alternative to uncertain future career prospects, or even represents an 'escape from unemployment' (see Oxenfeldt, 1943; Evans and Leighton, 1990; Storey, 1991 and 1994; Premand et al., 2012).

Thus entry may be determined by a set of different environmental factors including some 'progressive' determinants such as profitability and promising technological opportunities, but also 'regressive' determinants such as low wages and the actual condition of being (or the fear of becoming) unemployed (the latter conditions being particularly likely in a DC context).

Moreover, in determining new firm formation, these environmental drivers interact with the potential entrepreneur's personal traits.

Indeed, new firm founders differ with regard to characteristics such as previous work experience, family tradition, financial status, personal motivation. To start with, the founder of a new firm is heavily influenced by his/her own background, with particular reference to his/her previous job experience (see Evans and Leighton, 1989; Reynolds et al., 2001; Chlosta et al., 2012). The role of the family background in fostering entrepreneurship has been proved in the DCs, as well; for instance, Djankov et al. (2006a, 2006b and 2007) have shown that entrepreneurs in both China, Russia and Brazil are much more likely to have family members who are entrepreneurs as well as childhood friends who became entrepreneurs, suggesting that the family and the social environment play an important role in entrepreneurship.

Another important stream of literature has investigated the impact of financial constraints on business start-ups, mostly following on from the work by Fazzari, Hubbard and Petersen (1988). The fact that wealth, inheritance and windfall gains spur entrepreneurship suggests that business start-ups are often underfinanced (see Parker, 2004). Therefore, since most new companies need external capital, differences in the ability of capital markets to select and finance the most promising entrepreneurial projects may lead to important differences in the level and quality of entrepreneurship across countries, with DCs obviously suffering a disadvantage in this respect (Kerr and Nanda, 2011; Klapper, Amit and Guillén, 2010; see Section 2).

Other studies show that non-economic personal factors may turn out to be even more important than environmental variables. For instance, the potential entrepreneur 
seems to be strongly influenced by specific psychological attitudes, such as a desire to be independent, a search for autonomy in the workplace, an aspiration to full exploitation of previous job experience and acquired ability, a desire to be socially useful and to acquire improved social status (see Creedy and Johnson, 1983; Evans and Leighton, 1990; Vivarelli 1991 and 2004; Zacharakis, Bygrave and Shepherd, 2000).

If one takes into account the (often dominant) psychological attitudes discussed above, entry mistakes and excess entry can be further justified. In fact, the observed occurrence of these entry mistakes suggests an attitude which can be defined as a 'try and see' bet. Accordingly, market churning, turbulence and early failure, observed at a more aggregate level of analysis (see Section 1) emerge as normal and expected features of industrial dynamics.

These findings lead to the conclusion that several heterogeneous entry processes are simultaneously at play in the economy and that 'opportunity entrepreneurs', those bringing about innovation and economic growth, should be distinguished from 'revolving door' start-ups doomed to early failure and generating only precarious and temporary jobs (see Baumol 1990 and 2010).

Obviously enough, this distinction is a fortiori crucial when we focus on the DCs, where 'entrepreneurship' and 'self-employment' often generate informal and very transient activities not so very different from 'disguised unemployment'.

\section{Drivers of the post-entry performance of newborn firms}

Since entrepreneurs are embedded in different institutional contexts (see Sections 1 and 2) and are driven by both progressive and regressive determinants (see Section 3), the post-entry performance of newborn firms and their eventual contribution to economic development may be very diverse as well.

Indeed, from an empirical perspective, a relatively recent stream of literature has focused on the drivers of survival (or early exit) and growth of newborn firms (among the early studies, see, for instance: Reid, 1991; Boeri and Cramer, 1992; Baldwin and Rafiquzzaman, 1995). Within this field of research, it is possible to analyze the relationship 
between the ex-ante features of entry on the one hand, and both survival and - conditional on survival -the post-entry performance of newborn firms on the other. The following subsections are devoted to investigating what have been found to be the most important 'ex-ante' characteristics affecting the post-entry performance of new businesses.

\subsection{Size and age}

Many studies have discovered a positive relationship between start-up size and survival (see Audretsch and Mahmood, 1995; Mata, Portugal and Guimaraes, 1995; Agarval and Audretsch, 2001; for more controversial results, see Audretsch, Santarelli and Vivarelli, 1999a and $1999 b^{7}$ ). Since entry implies sunk costs (see Sutton, 1991) and generally occurs at a scale that is lower than the minimum efficient scale (MES), a larger entry size is a signal of commitment and self-confidence and makes both the occurrence of an entry mistake (see Section 4.2) and the risk of a failure due to diseconomies of scale less likely.

Moreover, a larger start-up size is positively correlated with other factors - such as lower credit constraints and a higher technological capability - which are predictors of a higher likelihood of survival and better post-entry performance (see Sections 4.3 and 4.5 below). Therefore, a larger start-up size can be definitely considered a reliable indicator of better chances of survival of the newborn firm.

On the other hand, a vast number of papers have found (conditional on survival), a negative relationship between start-up size and post-entry growth, thus rejecting Gibrat's Law (see Gibrat, 1931; Hall, 1987; Hart and Oulton, 1996; Sutton, 1997; Lotti, Santarelli and Vivarelli, 2003 and 2009). This evidence means that smaller entrants with a suboptimal entry size and with a higher risk of early failure (see above) must grow in order to survive and reach the MES as soon as possible. However, it is worth emphasizing that the (negative) relationship between size and growth has been found to be significant within the sub-sample of new entrants that struggle to survive (see Lotti, Santarelli, Vivarelli, 2003).

\footnotetext{
${ }^{7}$ However, as clarified by the authors, these results - in contrast with previous studies - may be due to the peculiarities of the Italian manufacturing sample used, dominated by micro-firms well below the minimum efficient scale. In this context characterized by a limited size variability, the positive impact of a larger scale might have been underestimated.
} 
Once market selection is accounted for, long run analyses have instead shown that a convergence towards Gibrat-like behavior can be detected among the survived most efficient firms (see Lotti, Santarelli and Vivarelli, 2006 and 2009; Daunfeldt and Elert, 2013). In other words, once small entrants have succeeded in approaching an efficient scale of production, their growth dynamics resembles more and more a stochastic process in which size and growth are independent.

Consistently, a firm's age turns out to be positively correlated with survival (that is the hazard rate is decreasing with age; see Fackler, Schnabel and Wagner, 2013) and negatively with growth (see Evans, 1987; Dunne and Hughes, 1994; Calvo 2006; Coad, Segarra and Teurel, 2013): experienced, mature firms are more able to deal with market dynamics and so more likely to stay in the market; however, once they have reached (or being very close to) the MES, they do not need to grow very fast ${ }^{8}$.

While all the studies cited so far concern developed countries, the evidence from DCs is similar. For instance, Das (1995), dealing with the Indian computer industry, found a significant negative relationship between firm growth and initial firm size; McPherson (1996), in a study on five southern African countries, detected a significant negative link between firm growth and both the firm's size and age; Goedhuys and Sleuwaegen (2000) and Sleuwaegen, L. and Goedhuys, M. (2002), respectively analyzing 141 and 129 manufacturing firms in Côte d'Ivoire, also found negative correlations between firm growth and both firm size and age; finally, running GMM-SYS panel estimates covering census-based Ethiopian manufacturing firms over the period 1996-2003, Bigsten and Gebreeyesus (2007) showed how the negative relationship between size and age on the one hand and firms' employment growth on the other is significant and robust to sample selection and unobserved firm heterogeneity ${ }^{9}$.

\footnotetext{
8 Moreover, recent literature has shown that firms' age may play a crucial role in shaping the relationship between size and firms' growth. In particular, Haltiwanger, Jarmin and Miranda (2013) - using data from the Census Bureau's Business Dynamics Statistics and Longitudinal Business Database - show that, once one controls for firm age, the negative relationship between size and growth either disappears or reverses the sign, due to the large share of exit among the smallest firms. As far as age is concerned, young firms are found to grow more rapidly than the mature ones; in this perspective start-ups are likely to play a key role in the job creation process. However, Haltiwanger, Jarmin and Miranda (2013) do not focus on start-ups, being most of their firms established incumbents; (for an analysis of the link between age and firm's performance, see also Coad, Segarra and Teruel, 2013).

${ }^{9}$ Consistent econometric outcomes in studies devoted to the DCs can also be found in Mead and Liedholm (1998); Gunning and Mengistae (2001); Bigsten and Söderbom (2006); Coad and Tamvada (2012).
} 
To sum-up, a larger start-up size is reassuring in terms of likelihood of survival and in making the job creation linked to the newborn firm not transitory; on the other hand, smaller new entrants - in order to survive - must grow rapidly and so they may also contribute to employment growth. However, in the latter case, the job creation effect involved by the surviving and fast-growing small entrants has to be compared with the massive job losses due to the early failure of most of the small newborn firms.

\subsection{Entrepreneurial learning}

From a theoretical point of view, Lucas (1978) was the first to put forward a theory of the size distribution of firms based on the relative endowment of entrepreneurial talents. However, the first author to represent the post-entry evolution of newborn firms formally was Boyan Jovanovic (1982) who proposed a Bayesian model of noisy selection, according to which efficient firms grow and survive, whereas inefficient ones decline and fail. The Jovanovic's model of entrepreneurial learning is perfectly consistent with a world where founders are quite heterogeneous in terms of both general and specific characteristics, entry mistakes can easily occur, entry can be originated by a 'try and see' bet and early failures are rather common (see previous sections; see also Hopenhayn, 1992; Ericson and Pakes, 1995).

If entrepreneurial learning is crucial and entry is often tentative, both spinoffs (entrepreneurs leaving a mother firm to found a new business) and 'serial entrepreneurs' (founders who have previously run other businesses) may have an advantage compared with "de novo" entrepreneurs ${ }^{10}$. For example, Hirakawa, Muendler and Rauch (2010), using microdata from Brazil over the 1995-2001 period, found that spinoffs are characterized by larger entry sizes (see Section 4.1) and lower exit rates than new firms not generated by a parent company. Similarly, the role of past experience and path-dependence is confirmed by the fact that serial entrepreneurs are more likely to replicate the success of

\footnotetext{
${ }^{10}$ For instance, Sørensen and Phillips (2011)argue that work experience in the prior firm shapes both the entrepreneur's competence and his/her commitment to the entrepreneurial role. However, while competence and information inherited from the mother firm provide an initial advantage, parental influence may generate inertia and resistance to change, unless the new company is able to create its unique competitive identity (see Ferriani, Garnsey and Lorenzoni, 2012).
} 
their past companies than single venture entrepreneurs or serial entrepreneurs who failed in their prior business (see Gompers et al., 2006).

Empirical studies on DCs provide support to the importance of entrepreneurial learning for post-entry performances of newborn firms either by observing the direct impact between experience and survival (Parker, 1997), or by showing that in contexts characterized by substantial absence of learning opportunities the average survival is quite short (Barr,1998). McPherson (1996) found a positive relationship between annual employment growth and previous experience of the founder in similar economic activities for entrepreneurial firms in Swaziland and Botswana, while Vijverberg (1991) and Goedhuys and Sleuwaegen (2000), both studying Côte d'Ivoire, found that job experience previously acquired in the same industry both increases the likelihood of founding a new business and contributes to a firm's better performance.

Nichter and Goldmark (2009) point to an additional channel by which learning on the job may positively affect the survival rate of newborn firms: indeed, previous work experience may expand entrepreneurs' social network, which in turn can positively affect post-entry performance (see also Barr, 1998; Kantis, Angelli and Koenig, 2004). However, the authors stress the differences between DCs and advanced countries for what concerns this link, the evidence about the DCs being quite controversial ${ }^{11}$.

Finally - turning our attention to a managerial and organizational perspective - new founders who had previously been employed as top managers in the same sector and who had better access to relevant information are expected to exhibit better post-entry business performance, due to their better ability in running and organizing complex activities (for an empirical validation of these relationships, see Cooper, Gimeno-Gascon and Woo, 1994; Cressy, 1996; Arrighetti and Vivarelli, 1999; Shane, 2001; Vivarelli, 2004).

\footnotetext{
${ }^{11}$ A recent article by Frankish et al. (2013) question the idea that previous work experience affects firms performances. They propose that there are good reasons to expect no significant effects of work experience, i.e. the importance of chance, entrepreneurs' propensity to optimism and the unlikely event that two business situations are really identical. They use UK data to show that there is no significant evidence about entrepreneurial learning. It must be noted, however, that such results could to some extent be due to the peculiarity of the sample they use, due to institutional specificities of the UK business environment.
} 


\subsection{Financial constraints}

Credit constraints and lack of financial capital in general should limit the rate of entry of new businesses, and both their likelihood of survival and rate of growth (see Carpenter and Petersen, 2002; Becchetti and Trovato, 2002; Aghion, Fally and Scarpetta, 2007). However, some recent microeconometric studies have shown that the role of credit rationing has been somewhat over-emphasized and that entrepreneurial saving plans may be able to overcome borrowing constraints (Cressy, 1996 and 2000; Parker, 2000; Hurst and Lusardi, 2004) ${ }^{12}$.

At any rate, new entrepreneurial initiatives in the DCs are credit-rationed in the vast majority of cases due to lack of collateral, informational asymmetries and largely imperfect local capital markets (see Section 2). For this reason, micro and small firms in DCs rarely apply for and receive formal bank loans, and rely instead on other sources of credit like trade credit, overdrafts and informal loans (Bigsten et al., 2003). Indeed, the lack of credit represents a severe impediment to growth of small firms in the early years of activity. For instance, Goedhuys and Sleuwaegen (2010), in a study investigating 947 small and medium entrepreneurial firms in several manufacturing firms in eleven Sub-Saharan African countries ${ }^{13}$, report that financial constraints are singled out as the major obstacle (from between eleven alternatives) to a firm's growth in 5 countries out of 11 . Consistently, in the previously-cited paper on Côte d'Ivoire by Goedhuys and Sleuwaegen (2000), the authors find that a lack of collateral significantly hampers firms' growth (ibidem, p.139). In this framework, the successful diffusion of microfinance in DCs can be seen as a way of reducing information and transaction costs in screening and financing small and new businesses (see Yunus, 1999; Fogel, Lee and McCumber, 2011).

A somewhat more skeptical position is put forth by Akoten, Sawada and Otsuka (2006), who carried out an econometric test of the effects of credit rationing on the growth of 225 micro and small garment firms in Nairobi. Their results show that credit access does

\footnotetext{
${ }^{12}$ The risk of overstating the hindering role of credit constraints is particularly high in questionnaire analyses where nascent or newborn entrepreneurs are asked to list their main difficulties in starting and/or running a new firm; in fact, they have the self-indulgent tendency to indicate a lack of external financial support as the main cause of their problems, while in most cases this is just a symptom of more fundamental deficiencies internal to the firm.

${ }^{13}$ The authors extracted their firm-level data from the World Bank Investment Climate Survey.
} 
not affect significantly firms' growth, and moreover the factors affecting credit access are clearly different from those affecting firms' growth.

\subsection{Education}

Not surprisingly, it has been demonstrated that education and human capital have an important role in increasing the likelihood of survival of new firms and in improving their post-entry economic performance (see Bates, 1990; Gimeno et al., 1997; Acs, Armington and Zhang, 2007). In particular, human capital aspects turn out to be particularly important in fostering entrepreneurship in the high-tech sectors; for instance, Baptista and Mendonça (2010) show that local access to knowledge and human capital significantly affect entry by knowledge-based firms, while Colombo and Grilli (2010) point out that the founder's human capital is a key driver of post-entry growth of high-tech start-ups.

Turning our attention to DCs and taking into account that in this context entrepreneurship and self-employment are often carried out within the informal sector of the economy, the impact of education turns out to be controversial. In fact, higher education augments the managerial capabilities which are necessary to run a business enterprise, but also increase the outside option for salaried employment in the formal sector of the economy. This is probably the reason why Van der Sluis, Van Praag and Vijverberg (2005), in their comprehensive survey, found that in the majority of DCs education lowers the likelihood of entering self-employment as contrasted with wage-earning employment.

In contrast, Goedhuys and Sleuwaegen (2000), running logit estimations on data concerning the owners of 141 manufacturing firms in Côte d'Ivoire, found that the probability of being an entrepreneur is strongly stimulated by both apprenticeship and formal education, with the positive effect of education steadily increasing going from lower to higher levels of education. Similarly, Ghani, Kerr, and O'Connell (2011), using cross-sectional establishment-level surveys of manufacturing and services companies in Indian districts, conclude that higher education in a local area significantly increases the supply of entrepreneurs. However, this relationship becomes non-significant when the informal manufacturing sector is taken into account. This is an interesting outcome and 
confirms the fact that education may render the choice of being a wage earner as preferable to entering self-employment in the informal sector (often characterized by 'defensive entrepreneurship, ${ }^{14}$ ).

The evidence concerning the relationship between education and the post-entry performance of new businesses in DCs may also look controversial on the surface. For example, Kantis, Angelli and Koenig (2004) show that secondary school attainment yield no discernible impact on firm growth in Latin America. On the contrary, other studies like for instance, Van der Sluis, Van Praag and Vijverberg (2005) conclude that an additional year of schooling raises entrepreneurial income by an average of $5.5 \%$; by the same token, McPherson (1996)found that in Botswana and Zimbabwe business owners who have completed secondary school run faster-growing firms than those proprietors with no schooling; finally, Goedhuys and Sleuwaegen (2000 and 2010),using data respectively from Côte d'Ivoire and from eleven Sub-Saharan African countries, found unequivocal evidence that formal education of the entrepreneur positively affect a firm's growth performance, respectively measured in terms of the growth rates of sales and employment (in both studies, the greatest effect on growth is found for entrepreneurs holding a university degree) $)^{15}$.

Nichter and Goldmark (2009) maintain that such apparent contradictions disappear if one takes into account a sort of "threshold effect" of education. Small firms with more educated owners are more likely to experience faster growth rates, but a country specific threshold should be reached in order for this effect to take place. For example, while in African countries the threshold enabling faster growth appears to be secondary school, in Latin America one can observe a higher threshold at the university level. Finally, it is also worth mentioning potential harmful effects of higher education, which may divert the attention of firms' owners to other business opportunities, who could end up paying little attention to the working of their actual business (Alvarez and Crespi, 2003).

\footnotetext{
${ }^{14}$ By the same token, Nafziger and Terrell (1996), using evidence from India, found that higher education of the founding entrepreneur reduces firm survival, indicating the importance of outside opportunities in paid wage employment within the formal sector.

${ }^{15}$ By the same token, Ligthelm (2011) found that business management skills are one of the strongest predictor of survival among small informal firms in South Africa.
} 


\subsection{Technological change}

If the underlying motivation to start a new firm is linked to innovative projects, then a better post-entry performance should be expected ${ }^{16}$. Empirically, this seems to be the case. In fact, a propensity for innovation emerges in general as a firm's growth driver (see, for instance, Coad and Rao, 2008; Altindag, Zehir and Acar, 2011; Colombelli, Krafft and Quatraro, 2014) and specifically as a positive predictor of survival and an above-theaverage post-entry performance of newborn firms (see Esteve-Pèrez, Sanchis and Sanchis, 2004; Raspe and Van Oort, 2008; Colombelli, Krafft and Quatraro, 2013) ${ }^{17}$.

Consistently with the discussion above, Cefis and Marsili (2006) found convincing evidence of an 'innovation premium' in survival time: using Pavitt's (1984) taxonomy, they showed that young firms (less than four years old) in the 'science-based' and 'specialized supplier' sectors were characterized by significantly higher chances of survival than firms in other sectors. More specifically, Cefis and Marsili (2005) have shown that being an innovator enhanced the expected time of survival by $11 \%$ compared with non-innovator counterparts.

However, the impact of innovation on post-entry performance of newborn firms is strictly related to sectoral differences and ultimately to the differential patterns of specialization of countries discussed in Section 1. Actually, entrepreneurial dynamics in DC is more likely to occur in sectors which are far from the technological frontier; therefore, the prevalence of traditional and mature sectors makes these contexts less fertile for innovation-driven entrepreneurship. According to Siqueira and Bruton (2010), hightechnology entrepreneurship in emerging economies is subject to greater resource constraints and higher levels of informality than in advanced countries. These two factors are likely to mitigate any possible positive effect of technology investments on firm performance.

\footnotetext{
${ }^{16}$ For an updated survey on the vast available micro-evidence on the link between innovation and productivity, see Mohnen and Hall, 2013). For a discussion of the key role of innovation and R\&D in young firms and SMEs in general, see Ortega-Argilés, Vivarelli and Voigt (2009) and Voigt and Moncada-PaternòCastello (2012).

${ }^{17}$ For instance, Arrighetti and Vivarelli (1999), after applying a factor analysis to a sample of 147 Italian spinoffs, found that innovative factors (related both to the innovative motivations of the founder and to his/her previous innovative experience in the mother firm) were significantly correlated with post-entry performance; their subsequent cluster analysis also revealed that the innovative group was more likely to have a better post-entry performance (see also Vivarelli and Audretsch, 1998).
} 
Moreover, as far as technological change is concerned, a distinction must be done between low-income and middle-income DCs. In fact, the middle-income DCs are mainly importing innovation produced elsewhere in the global economy, while the low-income ones are often completely excluded from any innovative process (see Robbins and Gindling, 1999; Robbins, 2003; Lall, 2004; Lee and Vivarelli, 2006; Srholec, 2011).

Finally, the international diffusion of technologies is likely to be grounded on creative rather than passive adoption (Antonelli, 2006); therefore, technological congruence, institutional setting and governmental arrangements shape a country's capacity to absorb knowledge and technologies produced elsewhere (see Dosi and Nelson, 2013). "Social capabilities" represent exactly the set of cultural, political, commercial, industrial and financial institutions which create the condition in catching-up countries to absorb and exploit the technologies developed elsewhere (Abramovitz, 1986). For example, a study conducted on Brasil, Russia, India and China (the so-called BRIC) confirmed that their institutional specificities play a major role in shaping their rapidly growing economies (Gupta et al., 2012; da Rocha, Ferreira da Silva and Carneiro, 2012; Kim, Park and Lee, 2013).

Nevertheless, in most DCs and even in BRIC, the role of R\&D-driven new firms and domestic NTBFs ${ }^{18}$ is extremely limited and so it is not surprising that very few studies try to link innovation with entrepreneurship within a DC context.

However, Santarelli and Tran (2011) studied entrepreneurship in Vietnam using a panel of regional-level data for 61 provinces over the period 2000-2008; among other outcomes, the author found that an innovative climate (proxied by the share of technical/R\&D personnel in the province) significantly and positively affects the regional net entry rate. As for post-entry performance, in the previously cited study by Goedhuys and Sleuwaegen (2010) on Africa, the innovative capability (proxied by a dummy for the introduction of new products) was found to increase a firm's annual employment growth by $2 \%$ on average.

\footnotetext{
${ }^{18}$ Rather, R\&D based initiatives in the DCs are often the outcome of the outsourcing by US, European and Japanese multinationals; see Moncada-Paternò-Castello, Vivarelli and Voigt, 2011.
} 


\subsection{Unemployment}

As far as unemployment (or the fear of becoming unemployed, see Section 3) is concerned, the literature points out two stylized facts: 1) those who start a new business as an escape from unemployment exit to a higher extent than those who have entered from paid employment (see Carrasco, 1999; Pfeiffer and Reize, 2000; for a slightly more optimistic evidence, Caliendo and Kritikos, 2010); 2) new founders who were formerly unemployed have on average lower economic outcomes and a lower propensity to contribute positively to job creation.

For instance, Arrighetti and Vivarelli (1999)found that defensive motivations such as concern about future career developments and the fear of becoming unemployed were predictors of a below-the-average post-entry evolution (ibidem, p. 936). By the same token, Andersson and Wadensjö, (2007), using a large sample of Swedish-born men who were self-employed in the period 1999-2002 and who were either wage-earners, unemployed or inactive in 1998, showed that those who were previously unemployed systematically had lower incomes compared to those who were previously wage earners; moreover, they also found that income from self-employment declines with the number of days spent in unemployment and that previously-unemployed entrepreneurs are significantly more likely to be 'solo' entrepreneurs, i.e. to have no employees.

As regards DCs, the literature is extremely scarce ${ }^{19}$. However, Wang (2006) found convincing evidence that unemployment had fostered start-ups in Taiwan (China) over the period 1986-2001; in contrast, in the previously-cited work by Santarelli and Tran (2011), no significant impact of the unemployment rate on new firm formation in Vietnam was found.

\subsection{Alien minorities}

A particular driver of new firm formation in DCs is the role played by ethnic minorities in generating above-the-average rates of entry and better post-entry performance

\footnotetext{
${ }^{19}$ This is unfortunate since, as discussed in Section 1, 'defensive and necessity entrepreneurs' appear to make up the bulk of self-employment in DCs, with activities ranging from street vending and small retailing to traditional personal services.
} 
among newborn firms. The basic hypothesis here is that alien minorities may have an entrepreneurial advantage based on their opportunity to exploit their minority community networks to overcome important hindrances to entrepreneurship (see Section 2), such as regulatory drawbacks, credit constraints and difficulties in accessing available inputs and technologies (see Kilby, 1983 and Biggs and Shah, 2006). In addition, from a sociological point of view, an ethnic minority, characterized by common traits such as language, culture and religion, generates trust, social cohesion and emulation, which are all factors that favor entrepreneurial behavior (see Greif, 1993; Hobday, 1995; Iyer and Schoar, 2010). Finally, a minority group may also be affected by a feeling of insecurity and frustration (in comparison with a dominant group), which encourages members to seek economic success and a better social status (see Elkan, 1988) ${ }^{20}$.

Empirical evidence is generally consistent with the hypotheses just discussed; for instance, Ramachandran and Shah (1999)-using firm level data from Kenya, Tanzania, Zambia and Zimbabwe and after controlling for firm size and age, various personal characteristics of the entrepreneurs, as well as sector and country differences -found that Asian and European firms start larger and grow faster than indigenously-owned African firms. By the same token, Hewitt and Wield (1997) show that Asian businesses in the Tanzanian manufacturing sector have a better access to sources of technology than indigenous companies. Consistently, in the previously-cited study by Goedhuys and Sleuwaegen (2000), the dummy variable ‘non-African' significantly and positively affects the likelihood of becoming an entrepreneur in Côte d'Ivoire. Similarly, when analyzing a randomly-selected sample of 296 Ethiopian SMEs, Mengistae (2001) finds that companies owned by the indigenous minority group of the Gurage perform better than average in the country; in particular, new businesses start larger and then grow faster. More recently, Goedhuys and Sleuwaegen (2010) show that the Asian dummy (equal to 1 for entrepreneurs of Lebanese, Indian, Middle Eastern or other Asian origin) turns out to be positive and significant in affecting firms' growth in Sub-Saharan Africa.

\footnotetext{
${ }^{20}$ This mechanism can work up to a given threshold; indeed to belong to a socioeconomically excluded group may decrease the likelihood of successfully found a new firm (this is the case, for instance, of the caste system in India, see Monsen, Mahagaonkar and Dienes, 2012).
} 


\section{Main findings and some policy suggestions}

If one conclusion can be drawn from this study is that 'entrepreneurship' is made by very different "animals". From a macroeconomic point of view, progressive new firm formation can generate permanent economic growth, while defensive and regressive startups originate only temporary positive effects, and ultimately market turbulence (see Sections1 and 2). From a microeconomic point of view, far from being solely the result of the entrepreneurial 'creative destruction' process proposed by Schumpeterian advocates (see Schumpeter, 1943), any set of entrepreneurial ventures can be seen as a rather heterogeneous aggregate where real and innovative entrepreneurs are to be found together with passive followers, over-optimistic gamblers and even escapees from unemployment (see Sections 3 and 4). Therefore, both scholars and policy makers should bear some important caveats in mind.

Firstly, since founders are heterogeneous and may make 'entry mistakes', most new firms are doomed to early failure; this type of entry is not conducive to technological renewal and economic growth, but simply to an excess of entries, market churning and turbulence. In both developed and developing countries, policy makers should discourage this type of venture.

Secondly, ex-ante features may be predictors of survival chances and post-entry business performance. For instance, a larger size, previous experience, the absence of credit constraints, higher education and innovation can be considered as positive predictors of a higher likelihood of survival, while infrastructural and institutional drawbacks, the absence of an adequate incubator background and a previous state of unemployment can be seen as predictors of early failure.

Policy makers need to be able to disentangle these drivers and encourage a selected subsample of potential entrepreneurs (see Santarelli and Vivarelli, 2002 and 2007; Mason and Brown, 2013). In the specific case of DCs, as well as a larger start-up size, higher education, longer previous job experience and innovative capabilities, the fact of belonging to an entrepreneurial ethnic minority (see Section 4.7) can be seen as an additional preferential trait when deciding how to target a policy addressed at sustaining progressive new firm formation. 
However, on average, the DCs appear to be strongly affected by regressive factors inducing "defensive" and "necessity" start-ups, often concentrated in the informal sectors and doomed to early failure. In this context, the widespread diffusion of general, 'ergaomnes' entry subsidies as policy instruments in the developing countries is unfortunate ${ }^{21}$ since they are very likely affected by standard policy failures, such as "deadweight" and "substitution” effects (see Vivarelli, 2012 and 2013). Indeed, 'umbrella' subsidies should be discarded in favor of selective and targeted measures addressed to the more promising potential entrepreneurs, such as those characterized by a superior human capital or by interesting and feasible innovative ideas.

Examples of targeted policy measures may include: 1) the public financial aid to innovative projects, otherwise neglected by a conservative and short-run-oriented capital market (see for instance the Korean government credit guarantee offered to technologybased SMEs suffering from funding problems; see Sohn and Kim, 2013); 2) the already mentioned (see Section 4.3) microcredit support, intended as a way of reducing those information and transaction costs - so common in the DCs - which affect both the screening and the financing of new promising businesses (see Yunus, 1999); 3) the public support to innovative start-ups generated by university spin-offs (for recent analyses of this perspective, see Bonaccorsi et al. 2013).

On the other hand, in the DCs more general market failures and regulatory constraints are obvious and severe, ranging from extreme financial rationing to lack of property rights, bribing, etc. (see Section 2). In this context, any entrepreneurial policy should consider a priority to remove the market, institutional and informational constraints which prevent potential entrepreneurs from starting a new business (see Acs and Virgill, 2009). From this respect, tailored subsidies and supports - as those briefly recalled above should be coupled with framework and infrastructural policies, able to improve the business climate where new ventures can find a proper environment to start and grow.

To sum up, a proper entrepreneurial policy in the DCs should be able to combine a comprehensive macroeconomic approach addressed to release the major institutional

\footnotetext{
${ }^{21}$ As correctly pointed out by Shane (2009, p. 41): "Policy makers believe a dangerous myth. They think that start-up companies are a magic bullet that will transform depressed economic regions, generate innovation, create jobs. This belief is flawed because the typical start-up is not innovative, creates few jobs, and generates little wealth".
} 
constraints to entrepreneurship with a selective microeconomic support to the most promising potential entrepreneurs.

\section{References}

Abramovitz, M. (1986), Catching Up, Forging Ahead, and Falling Behind, The Journal of Economic History, 46, 185-406.

Acs Z. J., Armington C. and Zhang T. (2007), The Determinants of New-firm Survival across Regional Economies: The Role of Human Capital Stock and Knowledge Spillover, Papers in Regional Science 86,367-91.

Acs, Z.J. and Audretsch, D.B. (1989a), Small-firm Entry in US Manufacturing, Economica, 56, $255-65$.

Acs, Z.J. and Audretsch, D.B. (1989b), Births and Firm Size, Southern Economic Journal 56, 46775.

Acs, Z.J. and Audretsch D.B. (1990), Innovation and Small Firms, Cambridge (Mass), MIT Press.

Acs, Z. and Virgill, N. (2009), Entrepreneurship in the Developing Countries, Jena Economic Research Paper n. 2009 - 23, Jena, Max Planck Institute of Economics.

Agarval, R. and Audretsch, D.B. (2001), Does Entry Size Matter? The Impact of the Life Cycle and Technology on Firm Survival, Journal of Industrial Economics, 49, 21-43.

Aghion,P., Fally. T. and Scarpetta, S. (2007), Credit Constraints as a Barrier to the Entry and Postentry Growth of Firms, Economic Policy, 22, 731-79.

Akoten, J. E., Sawada, Y., \& Otsuka, K. (2006), The determinants of credit access and its impacts on micro and small enterprises: The case of garment producers in Kenya. Economic Development and Cultural Change, 54(4), 927-944.

Altindag, E., Zehir, C. and Acar, A.Z. (2011), Strategic Orientations and their Effects on Firm Performance in Turkish Family Owned Firms, Eurasian Business Review, 1, 18-36.

Alvarez, R., \& Crespi, G. (2003), Determinants of technical efficiency in small firms. Small Business Economics, 20(3), 233-244.

Amorós, J.E. and Cristi, O. (2011) Poverty, human development and entrepreneurship, in Minniti, M. (ed.) The Dynamics of Entrepreneurship: Theory and Evidence, Oxford, Oxford University Press.

Amorós, J.E. and Cristi, O. (2008) Longitudinal analysis of entrepreneurship and competitiveness dynamics in Latin America, International Entrepreneurship and Management Journal, 381-399.

Andersson, P. and Wadensjö, E. (2007), Do the Unemployed Become Successful Entrepreneurs? International Journal of Manpower, 28, 604-26.

Antonelli, C. (2006), Diffusion as a process of creative adoption, Journal of Technology Transfer, 31, 211-226.

Arauzo-Carod, J.M. and Segarra-Blasco, A. (2005), The Determinants of Entry are not Independent of Start-up Size: Some Evidence from Spanish Manufacturing, Review of Industrial Organization, $27,147-65$. 
Ardagna, S. and Lusardi, A.M. (2010), Explaining International Differences in Entrepreneurship: The Role of Individual Characteristics and Regulatory Constraints, in Lerner, J. and A. Schoar (eds.), International Differences in Entrepreneurship, Chicago, University of Chicago Press, 17-62.

Arrighetti, A. and Vivarelli, M. (1999), The Role of Innovation in the Postentry Performance of New Small Firms: Evidence from Italy, Southern Economic Journal, 65, 927-39.

Aterido, R., Hallward-Driemeier, M. and Pagés, C. (2009), Big Constraints to Small Firms' Growth? Business Environment and Employment Growth Across Firms, World Bank Policy Research Working Paper 5032, Washington DC, World Bank.

Audretsch, D.B. (1995), Innovation and Industry Evolution, Cambridge (Mass), MIT Press.

Audretsch, D.B., Keilbach, M.C. and Lehmann, E.E. (2006), Entrepreneurship and Economic Growth, Oxford, Oxford University Press.

Audretsch, D.B. and Mahmood, T. (1995), New Firm Survival: New Results Using a Hazard Function, Review of Economics and Statistics, 77, 97-103.

Audretsch, D.B., Santarelli, E. and Vivarelli, M. (1999a), Start Up Size and Industrial Dynamics: Some Evidence from Italian Manufacturing, International Journal of Industrial Organization, 17, 965-83.

Audretsch, D.B., Santarelli, E. and Vivarelli, M. (1999b), Does Start Up Size Influence the Likelihood of Survival?, in Audretsch, D. and Thurik, R. (eds.), Innovation, Industry Evolution and Employment, Cambridge, Cambridge University Press, 280-96.

Ayyagari, M., Demirgüç-Kunt, A. and Maksimovic, V. (2008), How Important Are Financing Constraints? The Role of Finance in the Business Environment, World Bank Economic Review, 22, 483-516.

Baldwin, J.R. and Gorecki, P.K. (1987), Plant Creation Versus Plant Acquisition: The Entry Process in Canadian Manufacturing, International Journal of Industrial Organization, 5, 27-41.

Baldwin, J.R. and Gorecki, P.K. (1991), Firm Entry and Exit in the Canadian Manufacturing Sector, Canadian Journal of Economics, 24, 300-23.

Baldwin, J.R., and Rafiquzzaman, M. (1995), Selection Versus Evolutionary Adaptation Learning and Post-entry Performance, International Journal of Industrial Organization, 13, 501-22.

Banerjee, A. and Duflo, E., (2004), Do Firms Want to Borrow More? Testing Credit Constraints Using a Directed Lending Program, Banerjee, CEPR Discussion Papers n. 4681, London, CEPR.

Banerjee, A., Duflo, E. and Munshi, K. (2003), The (Mis)allocation of Capital, Journal of the European Economic Association, 1, 484-94.

Baptista R. and Mendonça, J. (2010), Proximity to Knowledge Sources and the Location of Knowledge-based Start-ups, Annals of Regional Science, 45, 5-29.

Barr, A. M. (1998), Enterprise performance and the functional diversity of social capital. Working paper number 65. Centre for the Study of African Economies, University of Oxford.

Bartelsman E., Haltiwanger, J. and Scarpetta, S. (2004), Microeconomic Evidence of Creative Destruction in Industrial and Developing Countries, World Bank Policy Research Working Paper3464, Washington DC, World Bank.

Bartelsman, E., Scarpetta, S. and Schivardi, F. (2005), Comparative Analysis of Firm Demographics and Survival: Evidence from Micro-level Sources in OECD Countries, Industrial and Corporate Change, 14, 365-91.

Bates, T. (1990), Entrepreneur Human Capital Inputs and Small Business Longevity, Review of Economics and Statistics, 72, 551-59. 
Baumol, W.J (1990), Entrepreneurship: Productive, Unproductive and Destructive, Journal of Political Economy, 98, 893-921.

Baumol, W.J (2010), The Microtheory of Innovative Entrepreneurship, Princeton and Oxford, Princeton University Press.

Becchetti, L. and Trovato, G. (2002), The Determinants of Growth for Small and Medium Sized Firms. The Role of Availability of External Finance, Small Business Economics, 19, 291-306.

Beck, T., Demirgüç-Kunt, A., Laeven, L. and Levine, R. (2008), Finance, Firm Size and Growth, Journal of Money, Credit and Banking, 40, 1379-405.

Beck, T., Demirgüç-Kunt, A. and Maksimovic, V. (2005), Financial and Legal Constraints to Growth: Does Firm Size Matter?, Journal of Finance, 60, 131-77.

Beesley, M.E and Hamilton, R.T. (1984), Small Firms' Seedbed Role and the Concept of Turbulence, Journal of Industrial Economics, 33, 217-31.

Biggs, T. and Shah, M.K. (2006), African SMEs, Networks and Manufacturing Performance, Journal of Banking and Finance, 30, 3043-66.

Bigsten, A. and Gebreeyesus, M. (2007), The Small, the Young and the Productive: Determinants of Manufacturing Firm Growth in Ethiopia, Economic Development and Cultural Change, 55, 81340.

Bigsten, A. and Söderbom, M. (2006), What Have We Learned from a Decade of Manufacturing Enterprise Surveys in Africa, World Bank Research Observer, 21, 241-65.

Bigsten, A., Collier, P., Dercon, S., Fafchamps, M., Gauthier, B., Gunning, J. W., et al.(2003), Credit constraints in manufacturing enterprises in Africa. Journal of African Economies, 12, 104125.

Boeri, T. and Cramer, U. (1992), Employment Growth, Incumbents and Entrants: Evidence from Germany, International Journal of Industrial Organization, 10, 545-66.

Bonaccorsi, A., Colombo, M.G., Guerini, M. and Rossi-Lamastra, C. (2013), University Specialization and New Firm Creation across Industries, Small Business Economics, 41, 837-63.

Caliendo, M. and Kritikos, A. (2010), Start-ups by the Unemployed: Characteristics, Survival and Direct Employment Effects, Small Business Economics, 35, 71-92.

Calvo, J.L. (2006), Testing Gibrat's Law for Small, Young and Innovating Firms, Small Business Economics, 26, 117-23.

Canales, R and Nanda, R. (2008), Harvard Business School Working Papersn. 08-101, Cambridge (Mass.), Harvard Business School.

Carpenter, R.E. and Petersen, B.C. (2002), Is the Growth of Small Firms Constrained by Internal Finance?, Review of Economics and Statistics, 84, 298-309.

Carrasco, R. (1999), Transitions to and from Self-employment in Spain, Oxford Bulletin of Economics and Statistics, 61, 315-41

Cefis, E. and Marsili, O. (2005), A Matter of Life and Death: Innovation and Firm Survival, Industrial and Corporate Change, 14, 1167-92.

Cefis, E. and Marsili, O. (2006), Survivor: The Role of Innovation in Firm's Survival, Research Policy, 35, 626-41.

Chlosta, S., Patzelt, H., Klein, S.B. and Dormann, C. (2012), Parental Role Models and the Decision to Become Self-employed: The Moderating Effect of Personality, Small Business Economics, 38, 121-38. 
Coad, A. and Rao, R. (2008), Innovation and Firm Growth in High-tech Sectors: A Quantile Regression Approach, Research Policy, 37, 633-48.

Coad, A., Segarra, A. and Teurel, M. (2013), Like milk or wine: Does firm performance improve with age?, Structural Change and Economic Dynamics, 24, 173-189.

Coad, A. and Tamvada, J. P. (2012), Firm Growth and Barriers to Growth among Small Firms in India, Small Business Economics, 39, 383-400.

Cole, S. (2009), Fixing Market Failures or Fixing Elections?Agricultural Credit in India, American Economic Journal: Applied Economics, 1, 219-50.

Colombelli, A., Krafft, J., Quatraro, F. (2014). High-growth firms and technological knowledge: Do gazelles follow exploration or exploitation strategies?, Industrial and Corporate Change, forthcoming, doi: 10.1093/icc/dtt053.

Colombelli, A., Krafft, J., Quatraro, F. (2013), Properties of knowledge base and firm survival: Evidence from a sample of French manufacturing firms, Technological Forecasting and Social Change, 80, 1469-1484.

Colombo, M.G., Delmastro M. and Grilli, L. (2004), Entrepreneurs' Human Capital and the Startup Size of New Technology-based Firms, International Journal of Industrial Organization, 22, 1183-211.

Colombo, M.G. and Grilli, L. (2010), On Growth Drivers of High-tech Start-ups: Exploring the Role of Founders'Human Capital and Venture Capital, Journal of Business Venturing, 25, 610-26.

Cooper, A.C., Gimeno-Gascon, F.J. and Woo, C.Y. (1994), Initial Human Capital and Financial Capital as Predictors of New Venture Performance, Journal of Business Venturing, 9, 371-96.

Creedy, J. and Johnson, P.S. (1983), Firm Formation in Manufacturing Industry, Applied Economics, 15, 177-85.

Cressy, R. (1996), Are Business Start-ups Debt-rationed?, Economic Journal, 106, 1253-70.

Cressy, R. (2000), Credit Rationing or Entrepreneurial Risk Aversion? An Alternative Explanations for the Evans and Jovanovic Finding, Economics Letters, 66, 235-40.

Da Rocha, A., Ferreira da Silva, J. and Carneiro, J. (2012), Entrepreneurship: The role of strategy and the institutional environment, in Brenes, E.R. and Haar, J. (eds) The future of entrepreneurship in Latin America, Palgrave MacMillan.

Das, S. (1995), Size, Age and Firm Growth in an Infant Industry: The Computer Hardware Industry in India, International Journal of Industrial Organization, 13, 111-126.

Daunfeldt, S. and Elert, N. (2013), When is Gibrat's Law a Law?, Small Business Economics, 41, $133-47$.

Dejardin, M. (2011), Linking Net Entry to Regional Economic Growth, Small Business Economics, $36,443-60$.

Desai, S. (2009), Measuring Entrepreneurship in Developing Countries, Research paper / UNUWIDER, No. 2009.10, ISBN 978-92-9230-179-8.

De Soto, H. (1989), The other path: The invisible revolution in the Third World. New York: Harper and Row.

Djankov, S., Qian, Y., Roland, G. and Zhuravskaya, E. (2006a), Entrepreneurship in China and Russia Compared, Journal of the European Economic Association, 4, 352-65.

Djankov, S., Qian, Y., Roland, G. and Zhuravskaya, E. (2006b), Who Are China's Entrepreneurs?, American Economic Review, 96, 348-52. 
Djankov, S., Qian, Y., Roland, G. and Zhuravskaya, E. (2007), What Makes a Successful Entrepreneur? Evidence from Brazil, Working Paper w0104, Center for Economic and Financial Research, Moscow, CEFIR.

Dosi, G. and Nelson, R.R. (2013), The Evolution of Technologies: An Assessment of the State-ofthe-Art, Eurasian Business Review, 3, 3-46..

Dunne, P. and Hughes, A. (1994), Age, Size, Growth and Survival: UK Companies in the 1980s, Journal of Industrial Economics, 42, 115-40.

Dunne, T., Roberts, M.J. and Samuelson, L. (1989), The Growth and Failure of US Manufacturing Plants, Quarterly Journal of Economics, 104, 671-98.

Elkan, W (1988), Entrepreneurs and Entrepreneurship in Africa, World Bank Research Observer, 3, 171-88.

Ericson, R. and Pakes, A. (1995), Markov-Perfect Industry Dynamics: a Framework for Empirical Work, Review of Economic Studies, 62, 53-82.

Esteve-Pérez S., Sanchis A. and Sanchis J. A. (2004), The Determinants of Survival of Spanish Manufacturing Firms, Review of Industrial Organization, 25, 251-73.

Evans, D.S. (1987), The Relationship Between Firm Growth, Size, and Age: Estimates for 100 Manufacturing Industries, Journal of Industrial Economics, 35, 567-81.

Evans, D.S. and Leighton L.S. (1989), Some Empirical Aspects of Entrepreneurship, American Economic Review, 79, 519-35.

Evans, L.B. and Leighton L.S. (1990), Small Business Formation by Unemployed and Employed Workers, Small Business Economics, 2, 319-30.

Fackler, D., Schnabel, C. and Wagner, J. (2013), Establishment Exits in Germany: The Role of Size and Age, Small Business Economics, 41, 683-700.

Fazzari, S.M., Hubbard, R.G. and Petersen, B.C. (1988), Financing Constraints and Corporate Investment, Brookings Papers on Economic Activity, 115, 695-713.

Ferriani, S., Garnsey, E. and Lorenzoni, G. (2012), Continuity and Change in a Spin-off Venture: The Process of Reimprinting,Industrial and Corporate Change, 21, 1011-48.

Fisman, R. and Svensson, J. (2007), Are Corruption and Taxation Really Harmful to Growth? Firm Level Evidence, Journal of Development Economics, 83, 63-75.

Fogel, K., Lee, K. and McCumber, W. (2011), Institutional Impact on the Outreach and Profitability of Microfinance Organizations, in Audretsch, D.B., Falck, O., Heblich, S. and Lederer, A. (Eds.), Handbook of Research on Innovation and Entrepreneurship, Cheltenham,Elgar, 119-33.

Foti, A. and Vivarelli, M. (1994), An Econometric Test of the Self-employment Model: The case of Italy, Small Business Economics, 6, 81-93.

Frankish, J.S., Roberts, R.G., Coad, A., Spears, T.C., and Storey, D.J. (2013), Do entrepreneurs really learn? Or do they just tell us that they do?, Industrial and Corporate Change, 22, 73-106.

Fritsch M. and Mueller P. (2007), The Persistence of Regional New Business Formation Activity Over Time. Assessing the Potential of Policy Promotion Programs, Journal of Evolutionary Economics, 17, 299-315.

Geroski, P.A. (1995), What do We know about Entry?, International Journal of Industrial Organization, 13, 421-40.

Geroski, P.A. and Schwalbach J. (eds.), (1991), Entry and Market Contestability: An International Comparison, Oxford, Basil Blackwell. 
Ghani, E., Kerr, W.R. and O'Connell, S.D. (2011b), Spatial Determinants of Entrepreneurship in India, NBER Working Paper 17514, Cambridge (Mass.), NBER.

Gibrat, R. (1931), Les Inegalites Economiques, Paris, Librairie du Recueil Sirey.

Gimeno, J, Folta, T., Cooper, A. and Woo, C. (1997), Survival of the Fittest? Entrepreneurial Human Capital and the Persistence of Underperforming Firms, Administrative Science Quarterly, $42,750-83$.

Goedhuys, M. and Sleuwaegen, L. (1999), Barriers to Growth of Firms in Developing Countries, Evidence from Burundi, in Audretsch, D. and Thurik, R. (eds), Innovation, Industry Evolution and Employment, Cambridge, Cambridge University Press, 297-314.

Goedhuys, M. and Sleuwaegen, L. (2000), Entrepreneurship and Growth of Entrepreneurial Firms in Côte d'Ivoire, The Journal of Development Studies, 36, 123-45.

Goedhuys, M. and Sleuwaegen, L. (2010), High-growth Entrepreneurial Firms in Africa: A Quantile Regression Approach, Small Business Economics, 34, 31-51.

Gompers, A., Kovner, A., Lerner, J. and Scharfstein, D. (2006), Skill vs. Luck in Entrepreneurship and Venture Capital: Evidence from Serial Entrepreneurs, NBER Working Paper12592, Cambridge (Mass.), NBER.

Greif, A. (1993), Contract Enforceability and Economic Institutions in Early Trade: The Maghribi Traders' Coalition, American Economic Review, 83, 525-48.

Gunning, J.W. and Mengistae, T. (2001), Determinants of African Manufacturing Investments: The Microeconomic Evidence, Journal of African Economies, 10, 48-80.

Gupta, V.K., Guo, C., Canever, M., Yim, Y.R., Sraw, G.K., and Liu, M. (2012), Institutional environment for entrepreneurship in rapidly emerging major economies: the case of Brazil, China, India, and Korea, International Entrepreneurship and Management Journal, forthcoming.

Hall, B. (1987), The Relationship Between Firm Size and Firm Growth in the US Manufacturing Sector, Journal of Industrial Economics, 35, 583-606.

Haltiwanger, J., Jarmin, R.S. and Miranda, J. (2013), Who Creates Jobs? Small versus Large versus Young, Review of Economics and Statistics, 95, 347-361.

Hamilton, R.T (1989), Unemployment and Business Formation Rates: Reconciling Time-series and Cross-section Evidence, Environment and Planning, 21, 249-55.

Hart, P.E. and Oulton, N. (1996), Growth and Size of Firms, Economic Journal, 106, 1242-52.

Hewitt, T. and Wield, D. (1997), Tanzanian Networks, Networks in Tanzanian Industrialization, Science and Public Policy, 24, 395-404.

Highfield, R. and Smiley, R. (1987), New Business Starts and Economic Activity: An Empirical Investigation, International Journal of Industrial Organization, 5, 51-66.

Hirakawa, O., Muendler, M. A. and Rauch, J. E. (2010), Employee Spinoffs and Other Entrants: Stylized Facts from Brazil, International Growth Centre Working Paper10/0879, London, LSE.

Hobday, M. (1995), Innovation in East Asia: The Challenge to Japan, Cheltenham, Elgar.

Hopenhayn, H. (1992), Entry, Exit and Firm Dynamics in Long Run Equilibrium, Econometrica $60,1127-1150$.

Hurst, E. and Lusardi, A. (2004), Liquidity Constraints, Household Wealth and Entrepreneurship, Journal of Political Economy, 112, 319-347.

Ihrig, J. and Moe, K.S. (2004), Lurking in the Shadows: The Informal Sector and Government Policy, Journal of Development Economics, 73, 541-57. 
Iyer, R. and Schoar, A. (2010), Are there Cultural Determinants of Entrepreneurship?, in Lerner, J. and A. Schoar (eds.), International Differences in Entrepreneurship, Chicago, University of Chicago Press, 209-40.

Johnson, P.S. (2005), Targeting Firm Births and Economic Regeneration in a Lagging Region, Small Business Economics, 24, 451-64.

Jovanovic, B. (1982), Selection and Evolution of Industry, Econometrica, 50, 649-70.

Kantis, H., Angelli, P., \& Koenig, V. M. (2004). Desarrollo emprendedor - América Latina y la experiencia internacional. Washington, DC: Inter-American Development Bank.

Kerr, W.R. and Nanda, R. (2011), Financing Constraints and Entrepreneurship, in Audretsch, D.B., Falck, O., Heblich, S. and Lederer, A. (Eds.), Handbook of Research on Innovation and Entrepreneurship, Cheltenham,Elgar, 88-103.

Kilby, P. (1983), The Role of Alien Entrepreneurs in Economic Development, an Entrepreneurial Problem, American Economic Review, Papers and Proceedings, 73, 107-11.

Kim, J.Y., Park, T.Y., and Lee, K. (2013), Catch-up by Indigenous Firms in the Software Industry and the Role of the Government in China: A Sectoral System of Innovation (SSI) Perspective, Eurasian Business Review, 3, 100-20..

Klapper, L. and Love, I. (2011), Entrepreneurship and Development: The Role of Information Asymmetries, World Bank Economic Review, 25, 1-8.

Klapper, L., Amit, R. and Guillén, M.F, (2010), Entrepreneurship and Firm Formation across Countries, in Lerner, J and Schoar (eds) International Differences in Entrepreneurship, Chicago, University of Chicago Press.

Klepper, S. (1997), Industry Life Cycles, Industrial and Corporate Change, 6(1), 145-81.

Knight, F.H. (1921), Uncertainty and Profit, New York, Houghton Mifflin.

Koellinger, P. and Thurik, A.R. (2012), Entrepreneurship and the Business Cycle, Review of Economics and Statistics, forthcoming (doi:10.1162/REST_a_00224) .

Kuznets S., (1930), Secular Movements in Production and Prices. Houghton Mifflin, Boston.

Lall, S. (2004), The Employment Impact of Globalization in Developing Countries, in Lee, E. and Vivarelli, M. (2004) (Eds), Understanding Globalization, Employment and Poverty Reduction, New York, Palgrave Macmillan, 73-101.

Lee, E. and Vivarelli, M. (2006), The Social Impact of Globalization in Developing Countries. International Labour Review, 145, 167-184.

Lee, S-H., Yamakawa, Y., Peng, M.W. and Barney, J.B. (2011), How Do Bankruptcy Laws Affect Entrepreneurship Development Around the World?, Journal of Business Venturing, 26, 505-20.

Lévesque, M. and Shepherd, D. A. (2004), Entrepreneurs' Choice of Entry Strategy in Emerging and Developed Markets, Journal of Business Venturing, 19, $29-54$.

Lian, Y., Sepehri, M. and Foley, M. (2011), Corporate Cash Holdings and Financial Crisis: An Empirical Study of Chinese Companies, Eurasian Business Review, 1, 112-24.

Ligthelm, A. (2011), Survival Analysis of Small Informal Businesses in South Africa, 2007-2010, Eurasian Business Review, 1, 160-79.

Little, I. M. D., Mazumdar, D., \& Page, J. W. Jr., (1987), Small manufacturing enterprises: A comparative analysis of India and other economies. New York: Oxford University Press.

Lotti, F., Santarelli, E. and Vivarelli, M. (2003), Does Gibrat's Law Hold Among Young, Small Firms?, Journal of Evolutionary Economics, 13, 213-35. 
Lotti, F., Santarelli, E. and Vivarelli, M. (2006), Gibrat's Law in a Medium-Technology Industry: Empirical Evidence for Italy, in Santarelli, E. (ed.), Entrepreneurship, Growth and Innovation: The Dynamics of Firms and Industries, New York, Springer, 149-64.

Lotti, F., Santarelli, E. and Vivarelli, M. (2009), Defending Gibrat's Law as a Long-Run Regularity, Small Business Economics, 32, 31-44.

Lucas, R.E., Jr. (1978), On the Size Distribution of Business Firms, Bell Journal of Economics, 9, $508-23$.

Malchow-Møller, N., Schjerning, B. and Sørensen, A. (2011), Entrepreneurship, Job Creation and Wage Growth, Small Business Economics, 36, 15-32.

Maloney, W. (2004), Informality Revisited, World Development, 32, 1159-78.

Mansfield, E. (1962), Entry, Gibrat's Law, Innovation and the Growth of Firms, American Economic Review, 52, 1023-51.

Marshall, A., 1919. Industry and Trade. A Study of industrial technique and business organization; and of their influences on the condition of various classes and nations. London: Macmillan and Co., Ltd.

Mason, C. and Brown, R. (2013), Creating Good Public Policy to Support High-growth Firms, Small Business Economics, 40, 211-25.

Mata, J., Portugal, P.and Guimaraes, P. (1995), The Survival of New Plants: Start-up Conditions and Post-entry Evolution, International Journal of Industrial Organization, 13, 459-82.

McPherson, M.A. (1996), Growth of Micro and small enterprises in Southern Africa, Journalof Development Economics, 48, 253-77.

Mead, D.C. and Liedholm, C. (1998), The Dynamics of Micro and Small Enterprises in Developing Countries, World Development, 26, 61-74.

Mengistae, T. (2001), Indigenous Ethnicity and Entrepreneurial Success in Africa: Some Evidence from Ethiopia,World Bank Policy Research Working Paper 2534, Washington DC, World Bank.

Mitra, R., \& Pingali, V. (1999), Analysis of growth stages in small firms: A case study of automobile ancillaries in India. Journal of Small Business Management, 37(3), 62-76.

Mohnen, P. and Hall, B.H. (2013), Innovation and Productivity: An Update, Eurasian Business Review, 3, 47-65.

Moncada-Paternò-Castello, P., Vivarelli, M. and Voigt, P. (2011), Drivers and Impacts in the Globalization of Corporate R\&D: An Introduction Based on the European Experience, Industrial and Corporate Change, 20, 585-603.

Monsen, E., Mahagaonkar, P. and Dienes, C. (2012), Entrepreneurship in India: The Question of Occupational Transition, Small Business Economics, 39, 359-82.

Nafziger, E.W. and Terrell, D. (1996), Entrepreneurial Human Capital and the Long-Run Survival of Firms in India, World Development, 24, 689-96.

Naudé, W.A. (2009), Out With the Sleaze, in With the Ease: Insufficient for Entrepreneurial Development?, UNU-WIDER Research Paper no. 2009/01, United Nations University, Helsinki.

Naudé, W. (2010), Entrepreneurship, Developing Countries, and Development Economics: New Approaches and Insights, Small Business Economics, 34, 1-12.

Naudé, W. Amorós, J.E. and Cristi, O. (2011), 'Surfeiting, The Appetite May Sicken': Entrepreneurship and the Happiness of Nations, Maastricht School of Management Working Paper No. 2011/07. 
Nichter, S. and Goldmark, L. (2009), Small Firm Growth in Developing Countries, World Development, 37, 1453-1464.

Ortega-Argilés R., Vivarelli, M. and Voigt, P. (2009), R\&D in SMEs: A Paradox?, Small Business Economics, 33, 3-11.

Oxenfeldt, A.R. (1943), New Firms and Free Enterprise: Pre-War and Post-War Aspects, Washington, American Council on Public Affairs.

Paravisini, D. (2008), Local Bank Financial Constraints and Firm Access to External Finance, Journal of Finance, 63, 2161-93.

Parker, S.C. (1997), The Effects of Risk on Self-employment, Small Business Economics,9, 515-22

Parker, S.C. (2000), Saving to Overcome Borrowing Constraints: Implications for Small Business Entry and Exit, Small Business Economics, 15, 223-32.

Parker, S.C. (2004), The Economics of Self-Employment and Entrepreneurship, Cambridge, Cambridge University Press.

Pavitt K. (1984), Sectoral Patterns of Technical Change: Towards a Taxonomy and a Theory, Research Policy, 13, 343-73.

Pfeiffer, F. and Reize, F. (2000), Business Start-ups by the Unemployed - An Econometric Analysis Based on Firm Data, Labour Economics, 7, 629-63.

Pisani, M. J., and Pagan, J. A. (2004), Self-employment in the era of the new economic model in Latin America: A case study from Nicaragua. Entrepreneurship \& Regional Development, 16(4), 335-350.

Porter, M. (1990). The competitive advantage of nations. New York: The Free Press.

Premand, P., Brodmann, S., Almeida, R., Grun, R. and Barouni, M. (2012), Entrepreneurship Training and Self-Employment among University Graduates. Evidence from a Randomized Trial In Tunisia, World Bank Policy Research Working Paper 6285, Washington DC, World Bank.

Rajan, R.G. and Zingales, L. (1998), Financial Dependence and Growth, American Economic Review, 88, 559-86.

Ramachandran, V. and Shah, M.K. (1999), Minority Entrepreneurs and Firm Performance in SubSaharan Africa, Journal of Development Studies, 36, 71-87.

Raspe, O. and Van Oort, F. G. (2008), Firm Growth and Localized Knowledge Externalities, Journal of Regional Analysis and Policy, 38, 100-16.

Reid, G.C. (1991), Staying in Business, International Journal of Industrial Organization, 9, 54556.

Reynolds, P.D., Camp, M. S., Bygrave, W.D., Autio, E. and Hay, M. (2001), Global Entrepreneurship Monitor. 2001 Summary Report, London, London Business School and Babson College.

Robbins, D. (2003), The Impact of Trade Liberalization upon Inequality in Developing Countries A review of Theory and Evidence. ILO Working Paper, n.13, Geneva, International Labour Organization.

Robbins, D. and Gindling, T.H. (1999), Trade Liberalization and the Relative Wages for MoreSkilled Workers in Costa Rica. Review of Development Economics, 3, 140-154.

Santarelli, E., Carree, M. and Verheul, I. (2009), Unemployment and Firm Entry and Exit: An Update on a Controversial Relationship, Regional Studies, 43, 1061-73. 
Santarelli, E. and Tran, H. T. (2011), Growth of Incumbent Firms and Entrepreneurship in Vietnam, Working Papers DSE n. 785, Bologna, Dipartimento Scienze Economiche - Universita' di Bologna.

Santarelli, E. and Vivarelli, M. (2002), Is Subsidizing Entry an Optimal Policy?, Industrial and Corporate Change, 11, 39-52.

Santarelli, E. and Vivarelli, M. (2007), Entrepreneurship and the Process of Firms' Entry, Survival and Growth, Industrial and Corporate Change, 16, 455-88.

Schiffer, M., and Weder, B. (2001). Firm size and the business environment: Worldwide survey results. IFC working paper number 43. Washington, DC: International Finance Corporation.

Schumpeter, J.A. (1934), The Theory of Economic Development, Cambridge (Mass.), Harvard University Press.

Schumpeter, J.A. (1939), Business Cycles: A Theoretical, Historical and Statistical Analysis of the Capitalist Process, New York, McGraw-Hill.

Schumpeter, J.A. (1943), Capitalism, Socialism and Democracy, New York, Harper.

Shane, S. (2000), Prior Knowledge and the Discovery of Entrepreneurial Opportunities, Organization Science, 11, 448-69.

Shane, S. (2001), Technological Opportunities and New Firm Creation, Management Science, 47, 205-20.

Shane, S. (2009), Why Encouraging More People To Become Entrepreneurs Is Bad Public Policy", Small Business Economics, 33, 141-49.

Siqueira, A. and Bruton, G.D. (2010), High-technology entrepreneurship in emerging economies: Firm informality and contextualization of resource-based theory, IEEE Transactions on Engineering Management, 57, 39-50.

Sleuwaegen, L. and Goedhuys, M. (2002), Growth of Firms in Developing Countries, Evidence from Côte d'Ivoire, Journal of Development Economics, 68, 117-35.

Sohn, S. Y. and Kim, Y. S. (2013), Behavioral Credit Scoring Model for Technology-based Firms that Considers Uncertain Financial Ratios Obtained from Relationship Banking, Small Business Economics, 41, 931-43.

Sonobe, T., Akoten, J.E. and Otsuka, K. (2011), The Growth Process of Informal Enterprises in Sub-Saharan Africa: A Case Study of a Metalworking Cluster in Nairobi, Small Business Economics,36, 323-35.

Sørensen, J.B. andPhillips, D.J. (2011),Competence and Commitment: Employer Size and Entrepreneurial Endurance, Industrial and Corporate Change, 20, 1277-304.

Srholec, M. (2011), A Multilevel Analysis of Innovation in Developing Countries, Industrial and Corporate Change, 20, 1539-69.

Stam E. (2007), Why Butterflies Don't Leave. Locational Behavior of Entrepreneurial Firms, Economic Geography, 83, 27-50.

Storey, D.J. (1991), The Birth of New Firms - Does Unemployment Matter? A Review of the Evidence, Small Business Economics, 3, 167-78.

Storey, D. J. (1994), Understanding the Small Business Sector, London, Routledge.

Sutton, J. (1991), Sunk Costs and Market Structure, Cambridge (Mass.), MIT Press. 
Sutton, J. (1997), Gibrat's Legacy, Journal of Economic Literature, 35, 40-59.

Tybout, J.R. (2000), Manufacturing Firms in Developing Countries: How Well Do They Do and Why?, Journal of Economic Literature, 38, 11-44.

Van der Sluis, J., Van Praag, M. and Vijverberg, W. (2005), Entrepreneurship Selection and Performance: A Meta-analysis of the Impact of Education in Developing Economies, World Bank Economic Review, 19, 225-61.

Van Praag, M.C. and Versloot, P.H. (2007), What Is the Value of Entrepreneurship?, A Review of Recent Research, Small Business Economics,29, 351-82.

Vial, V. and Hanoteau, J. (2010), Corruption, Manufacturing Plant Growth, and the Asian Paradox: Indonesian Evidence, World Development, 38, 693-705.

Vijverberg, W. (1991), Profits from Self-Employment: The Case of Côte d'Ivoire, World Development, 19, 683-96.

Vivarelli, M. (1991), The Birth of New Enterprises, Small Business Economics, 3, 215-23.

Vivarelli, M. (2004), Are All the Potential Entrepreneurs So Good?, Small Business Economics, 23, 41-9.

Vivarelli, M. (2007), Entry and Post-Entry Performance of Newborn Firms, London, Routledge.

Vivarelli, M. (2012), Drivers of Entrepreneurship and Post-Entry Performance, Policy Research Working Paper n.6245, Washington, World Bank.

Vivarelli, M. (2013), Is Entrepreneurship Necessarily Good? Microeconomic Evidence from Developed and Developing Countries, Industrial and Corporate Change, 22, 1453-95.

Vivarelli, M. and Audretsch, D.B. (1998), The Link between the Entry Decision and Post-entry Performance: Evidence from Italy, Industrial and Corporate Change, 7, 485-500.

Voigt, P. and Moncada-Paternò-Castello, P. (2012), Can Fast Growing R\&D-Intensive SMEs Affect the Economic Structure of the EU Economy? A Projection to the Year 2020, Eurasian Business Review, 2, 96-128.

Wang, S. (2006), Determinants of New Firm Formation in Taiwan, Small Business Economics, 27, 313-23.

Wennekers, S. and. Thurik, A.R. (1999), Linking Entrepreneurship and Economic Growth, Small Business Economics, 13, 27-55.

Wennekers, S., van Stel, A.J., Thurik, A.R. and Reynolds, P.D. (2005), Nascent Entrepreneurship and the Level of Economic Development, Small Business Economics, 24, 293-309.

Winter, S.G. (1991), On Coase, Competence, and the Corporation, in Williamson, O.E. and Winter, S.G. (eds.), The Nature of the Firm: Origins, Evolution and Development, Oxford, Oxford University Press, 179-95.

Yunus, M. (1999), Banker to the Poor, London, Aurum Press.

Zacharakis, A.L., Bygrave, W.D. and Shepherd, D.A. (2000), Global Entrepreneurship Monitor. National Entrepreneurship Assessment: United States of America, 2000 Executive Report, Babson Park (Mass), Babson College. 